\title{
Constraints of native cattle genetic resource conservation and features of breeding system in representative areas of Bangladesh
}

\author{
M. A. Quddus ${ }^{1}$ and M. R. Amin ${ }^{2}$ \\ ${ }^{1}$ Department of Agricultural Statistics and ${ }^{2}$ Department of Animal Breeding and Genetics, Bangladesh Agricultural \\ University, Mymensingh-2202, Bangladesh
}

\begin{abstract}
The study was undertaken to identify the constraints of native cattle genetic resource conservation at the farm level along with their features of breeding system and profitability. Five different study sites like south-west, northern hills, industrial zone, north-west and mid-region were selected representatively from all over the country. A total of 280 cattle farmers from the selected regions were interviewed. A multiple regression model was fitted to know the impact of contributing factors on lactation characteristics of cows. The double log linear model was also used to explore the input-output relationship of milk production. Average milk yield was 1.78 and 5.64 liter per day per cow respectively for native and crossbred cow. Contribution of age, order of lactation and stage of lactation were predictable in native cattle but not in crossbreds. Livestock farming contributed 36.4 percent of total income of the farmers studied. A crossbred cattle farming was profitable but native cattle farming was non-profitable. Indigenous cattle were preferred over crossbred due to their superior adaptability to local environmental stresses, rearing ease, low input, lesser proneness to disease and availability of native bull for mating. Per farm average number of milch cow was found to be reduced day by day and maximum number was 4 in a farm during the period 2006-07. Major causes of reduction were the non-profitability, crisis of feed, lack of investment, introduction of exotic breed etc. Responded farmers had no clear idea on conservation of native cattle.
\end{abstract}

Keywords: Genetic resource, Conservation, Breeding system, Profitability assessment

\section{Introduction}

Indigenous cattle play a crucial role in the livelihood system and well-being of the traditional rural farmers of Bangladesh and thereby taking part significantly in meeting the Millennium Development Goal (MDG). Local cattle are integral contributor of food, agricultural power, agrarian culture and heritage and biodiversity as well (FAO, 2007a). But as they are low input low producing animal, they are being gradually substituted by high producing exotic cattle or crosses thereof with a trend toward monoculture animal production. It is reported that almost one breed of domestic species was disappeared per month within the period from 2000-2006 (FAO, 2008) over the globe. Around 20 percent of the reported breeds are classified at risk (FAO, 2007b). Breed substitution or withdraw of indigenous stocks currently in force all on a sudden will likely cause a linear rise of unemployment with the people associated with traditional farming leading to an inevitable catastrophe in the rural economy. Furthermore, a degradation of agroecosystem is very likely to occur if well balanced biodiversity gets interrupted in which native cattle genetic resource is a vital component. Considering the severity of the malady FAO through its daughter organizations already gathered country driven reports for risk status assessment and developed action plan on benefit-sharing management and sustainable use of Farm Animal Genetic Resources (FAnGR) all over the world (FAO, 2007b, Gibson et al., 2005). Small holder farming system, as it predominantly prevailing in our country, support mostly subsistence and not market orientation. Indigenous livestock breeds, despite having valuable adaptive traits, low productivity diminishes their survival value necessitating conservation (Sahai, 2001). Therefore, development of strategies for conservation of animals like local cattle needs consideration of multiple factors involved in biology of animals, agroecology of the environment, husbandry system of the animals, purpose of rearing and affordability of the owners duly to be addressed (Bayer et al., 2001).

Not enough field works on this aspect have been accomplished all over the world (Annonym, 2006 and Annonym, 2007). It is only recently, with the FAO's initiatives a number of researchers have taken programme to evaluate and conserve FAnGR. Hodges (2002) demonstrated the need of conservation of farm animals for maintaining biodiversity. According to Bhuiyan (2001) a thorough economic and biological appraisal of native animal genetic resource for their relative importance and appropriateness in situ has yet to be attempted in Bangladesh. Farm level situations of breeding status, preference of native cattle by the small holder cattle farmers, causes of reduction of native cattle and profitability differences 
between native and crossbred cattle should be taken into account while developing sustainable conservation strategy. Envisaging the perspectives highlighted so far the current research was undertaken to focus insights of indigenous cattle husbandry in rural community with particular reference to constraints and options for conservation in situ. Therefore, the objective of the present study is to identify the constraints of native cattle genetic resource conservation with particular reference to features of their breeding system and profitability assessment.

\section{Materials and Methods}

Five representative study sites were selected from all over the Bangladesh in order to economize time and labour. These were (i) south-west region (Jessore district) (ii) northern hill sties (Sherpur district) (iii) industrial zone having high employment opportunity (Gazipur district) (iv) resource poor area and northwest region of the country (Bogra district) and ( $v$ ) region between two extremes or mid-region of the country (Mymensingh district). These five regions were considered as the five strata of the whole sampling technique. For convenient mode of selection, one random upazila from each of the regions was selected. Three adjacent villages from each upazila were selected using random sampling technique. A total of 280 cattle farmers from the selected villages were interviewed through an interview schedule. The data collection was started from November 2006 and ended in October 2007 and the study was ended in December 2008.

To know the impact of different contributing factors of lactation characteristics on cow the following multiple regression model was used:

$$
Y=b_{0}+b_{1} X_{1}+b_{2} X_{2}+b_{3} X_{3}+U_{i}
$$

Where,

$$
\begin{aligned}
& Y=\text { Milk production (L/cow/day) } \\
& b_{0}=\text { Inercept } \\
& X_{1}=\text { age of milch cow (in year) } \\
& X_{2}=\text { Order of lactation } \\
& X_{3}=\text { Stage of lactation in a particular lactation order } \\
& b_{1}, b_{2} \text { and } b_{3} \text { are the regression coefficients of respective variables, and } \\
& U_{i}=\text { Error term. }
\end{aligned}
$$

The double log linear multiple regression model was used to explore the input-output relationship of milk production. The general specification of model is shown as follows:

$$
\operatorname{LnY}=\operatorname{LnB}_{0}+b_{1} \operatorname{LnX}_{1}+b_{2} \operatorname{LnX}_{2}+b_{3} \operatorname{LnX} X_{3}+b_{4} \operatorname{LnX}_{4}+U_{j}
$$

Where,

$$
\begin{aligned}
& Y=\text { milk output (in taka per household per day) } \\
& X_{1}=\text { length of experience of cow owner in farming (year) } \\
& X_{2}=\text { year of schooling of cow owner } \\
& X_{3}=\text { farm size based on cultivated land (ha) } \\
& X_{4}=\text { time devoted in dairy farming (hours per day) } \\
& b_{1} \text { to } b_{4} \text { are the respective regression coefficients } \\
& U_{j} \text { is the random term. }
\end{aligned}
$$

Benefit cost ratio (BCR) was calculated as follows according to Singh (1977):

$$
\mathrm{BCR}=\frac{\text { Net return per cow per day }}{\text { Total cost per cow per day }}
$$




\section{Results and Discussion}

Of the farm house surveyed cattle herd size averaged 4.19 and in it 1.37 cows were in milk (Table 1). In addition to non milkier cattle farmers were found to own one or more milch cows. Men employ their labour more than do women both in number and time per day. Some $65.7 \%$ cattle were produced in farmers own herd and 34.3 percent were bought. More than 76 percent farmers still relish native bovines probably because of their affinity to traditional farming system. Highest coat colour preference is Black-white (60\%) for local cow and White-Black (41\%) for crossbred cow (Table 1).

Table 1. Farm house characteristics

\begin{tabular}{|l|c|c|c|r|}
\hline Characteristics & Mean & S. D. & Characteristics & Percent \\
\hline Number of cattle/household & & & Source of milch cow procurement & \\
\hline Milch cow & 1.37 & 0.680 & Own herd & 65.7 \\
\hline Dry & 0.33 & 0.586 & Bought before puberty & 21.8 \\
\hline Bull & 0.61 & 0.909 & Bought during pregnancy or in milk & 12.5 \\
\hline Calf & 1.88 & 0.939 & Preference on cow type (0-100 score) & \\
\hline Total cattle & 4.19 & 1.925 & Native & 76.4 \\
\hline Man power involved in farming \\
\begin{tabular}{|l|l|l|r|}
$\mid$ \\
Man
\end{tabular} & 1.14 & 0.489 & Crossbred & 20.4 \\
\hline Women & 0.94 & 0.373 & Preference on coat colour (0-100 score) & 3.2 \\
\hline Children & 0.31 & 0.550 & Local : Black-white & 60.0 \\
\hline Overall & 2.23 & 0.788 & Brownish & 18.0 \\
\hline Labour (Man-hour/day/farm) & & & Red & 22.0 \\
\hline Man & 2.20 & 1.990 & Cross : Light red & 27.2 \\
\hline Women & 2.10 & 1.850 & Deep red & 31.8 \\
\hline Children & 0.14 & 0.405 & White-black & 41.0 \\
\hline Hired & 0.31 & 1.180 & & \\
\hline Total & 4.74 & 4.038 & & \\
\hline
\end{tabular}

Source: Own calculation from the surveyed data

Farmers' source of breeding bulls was from their own, neighbour's herd, rent or exchange. Cows mated with bulls available in the neighbour's herd figured more than 85 percent and other sources shared only nearly 15 percent. Around 76.4 percent cases were pure breeding among the natives, 20.4 percent were crossbreeding and only 3.2 percent cases had no option (Table 2). Three quarter of the cow population was being mated still naturally and Al coverage remains close to 23\%. Among the Al services, around $25 \%$ of cows were provided service by the private sector (mostly BRAC) and Government sub center and points share about 27 and 39 percent respectively (Table 2 ).

Table 2. Options for breeding and mating system

\begin{tabular}{|l|r|l|l|l|}
\hline Breeding management & Percent & & Breeding management & Percent \\
\hline Source of breeding bull & & & Mating system & \\
\hline Own herd & 9.3 & & Natural uncontrolled & 1.4 \\
\hline Neighbour's herd & 85.1 & & Natural controlled & 75.4 \\
\hline Rent / Exchange / DLS & 5.6 & & Artificial insemination (AI) & 23.2 \\
\hline Breeding system option & & & Place of Al & \\
\hline Pure breeding & 76.4 & & Al Centre & 9.2 \\
\hline Crossbreeding & 20.4 & & Al Sub-Centre & 27.2 \\
\hline No choice & 3.2 & & Al Point & 38.5 \\
\hline & & & BRAC / Private & 24.6 \\
\hline
\end{tabular}

Source: Own calculation from the surveyed data

Milk production of a cow depends on genetic make up of the cow, nutritional status and environmental interaction with genotypes. Lactation length of cow was considered as the most important determinant of profitability of dairy farm. Farmers in the study area do not keep records but rely on their memory. This is common situation in developing countries (Nuru and Dennis, 1976) resulting in a major handicap to breed improvement. Milk yield $(L)$ per cow per day ranged between 1.5 and 2.0 with an average of 1.78 in native 
and ranged between 5.0 and 9.0 with an average of 5.64 in crossbred cows from $1^{\text {st }}$ to $8^{\text {th }}$ lactation. Native cows gave peak yield during $2^{\text {nd }}$ and $3^{\text {rd }}$ month while crossbred cows gave peak yield in $7^{\text {th }}$ month of lactation (Table 3). No distinct calving season was observed in cows of both native and crossbred types. This is common with most communities found in tropical Africa (Wilson and Clarke, 1975; de Leeuw and Wilson, 1987). Lactation length of 85 percent cows studied was 7 month and in few cases it extended up to 15 months, especially, for crossbred cows.

Table 3. Lactation characteristics and milk yield of the cow surveyed

\begin{tabular}{|c|c|c|c|c|c|c|c|}
\hline \multirow{2}{*}{$\begin{array}{c}\text { Lactation } \\
\text { order }\end{array}$} & \multirow[t]{2}{*}{ Percent } & \multicolumn{2}{|c|}{ Average milk yield (L) } & \multirow{2}{*}{$\begin{array}{l}\text { Month of } \\
\text { lactation }\end{array}$} & \multirow[t]{2}{*}{ Percent } & \multicolumn{2}{|c|}{ Average milk yield (L) } \\
\hline & & Native & Crossbred & & & Native & Crossbred \\
\hline 1 & 14.6 & $1.6(36)$ & $5.1(05)$ & 1 & 7.5 & $1.9(13)$ & $5.3(8)$ \\
\hline 2 & 35.0 & $1.9(72)$ & $6.3(26)$ & 2 & 9.6 & $2.0(22)$ & $4.7(5)$ \\
\hline 3 & 25.4 & $1.7(50)$ & $5.2(21)$ & 3 & 20.4 & $2.0(41)$ & $5.4(16)$ \\
\hline 4 & 10.0 & $1.9(18)$ & $4.6(10)$ & 4 & 15.7 & $1.9(36)$ & $6.3(8)$ \\
\hline 5 & 5.7 & $1.7(14)$ & $9.0(02)$ & 5 & 12.5 & $1.7(30)$ & $4.5(5)$ \\
\hline 6 & 4.6 & $2.0(11)$ & $5.0(02)$ & 6 & 11.4 & $1.6(27)$ & $6.3(5)$ \\
\hline 7 & 3.2 & $1.7(09)$ & - & 7 & 7.5 & $1.8(16)$ & $8.0(5)$ \\
\hline \multirow[t]{2}{*}{8} & 1.4 & $1.5(04)$ & - & 8 & 5.0 & $1.4(11)$ & $5.7(3)$ \\
\hline & & & & 9 & 6.4 & $1.4(11)$ & $5.4(7)$ \\
\hline \multicolumn{2}{|c|}{ Overall milk yield/cow } & 1.78 & 5.64 & $10-15$ & 4.0 & $1.2(07)$ & $4.9(4)$ \\
\hline
\end{tabular}

Source: Own calculation from the surveyed data

Figures in the parentheses indicate number of milch cow.

Table 4 shows that cow age (positively), order and stage of lactation (negatively) all affected milk production significantly (0.001) in native cows which meant that productivity declined with the progress of cow parity and milking stage within a lactation. Increased age lowered milk production $(p<0.05)$ in crossbreds but lactation order and stage did not influence $(p>0.05)$ milk yield. Results interpret that contribution of age, order of lactation and stage of lactation are predictable in native cows but not in crossbreds. It might be because of variable environments in which crossbreds were kept and also for their variable degree of inheritance level as well as health condition.

Table 4. Estimated values of regression coefficients and related statistics of milk production

\begin{tabular}{|l|c|c|c|}
\hline \multicolumn{1}{|c|}{ Independent variables } & $\begin{array}{c}\text { Native cattle } \\
\mathrm{N}=214\end{array}$ & $\begin{array}{c}\text { Crossbred } \\
\mathrm{N}=57\end{array}$ & $\begin{array}{c}\text { Both native and crossbred } \\
\mathrm{N}=271\end{array}$ \\
\hline Intercept & $1.983^{\star \star}$ & $7.047^{\star *}$ & $2.690^{\star \star}$ \\
& $(0.133)$ & $(1.426)$ & $(0.438)$ \\
\hline Age of milch cow $\left(\mathrm{X}_{1}\right)$ & $0.165^{\star \star}$ & $-0.708^{\star}$ & 0.197 \\
& $(0.054)$ & $(0.339)$ & $(0.153)$ \\
\hline Order of lactation $\left(\mathrm{X}_{2}\right)$ & $-0.238^{\star \star}$ & 1.067 & -0.372 \\
& $(0.081)$ & $(0.617)$ & $(0.235)$ \\
\hline Stage of lactation $\left(\mathrm{X}_{3}\right)$ & $-0.115^{\star \star}$ & 0.050 & -0.038 \\
& $(0.019)$ & $(0.124)$ & $(0.054)$ \\
\hline $\mathrm{R}^{2}$ & 0.156 & 0.078 & 0.011 \\
\hline
\end{tabular}

Figures within parentheses indicate standard error.

* and ${ }^{* *}$ indicates significant level at 5 and 1 percent respectively.

The main sources of income of the cattle holders studied were the livestock and crop cultivation. The secondary sources were the non-farm activities like service and business. Total income of the cattle owners ranged from Tk.350 to Tk.26,200 with an average income of Tk.5,453 per month. Livestock farming contributed 36.4 percent of their total income. Highly significant positive correlation $(r=0.465)$ between total income and income from livestock indicate that income from livestock had significant contribution to the cattle owner's family expenditure. Only 24.3 and 27.5 percent of the sample households respectively had source of service and business. The detailed pattern of income of the sample households is shown in Table 5. 
Table 5. Monthly income distribution of the cattle owners

\begin{tabular}{|c|c|c|c|c|c|c|}
\hline \multirow[t]{2}{*}{ Source of income } & \multicolumn{2}{|c|}{ Farmers } & \multicolumn{3}{|c|}{$\begin{array}{c}\text { Item-wise income of per farm } \\
\text { household (Taka) }\end{array}$} & \multirow{2}{*}{$\begin{array}{c}\text { Average income o } \\
\text { all households } \\
\text { (Taka) }\end{array}$} \\
\hline & Number & $\%$ & Minimum & Maximum & Average & \\
\hline Total & 280 & 100 & 350 & 26,200 & 5,453 & 5,453 \\
\hline Livestock & 280 & 100 & 330 & 21,000 & 1,984 & 1,984 \\
\hline Crop & 178 & 63.6 & 300 & 25,000 & 2,919 & 1,855 \\
\hline Service & 68 & 24.3 & 700 & 6,000 & 2,932 & 712 \\
\hline Business & 77 & 27.5 & 900 & 12,000 & 2,896 & 790 \\
\hline Others & 11 & 3.9 & 300 & 800 & 527 & 021 \\
\hline
\end{tabular}

Source: Own calculation from the surveyed data

The coefficient of multiple determination, $\mathrm{R}^{2}$ for three groups of cattle holders were $0.478,0.967$ and 0.983 respectively (Table 6) which indicates that the variables included in the model explained lower variability in case of native cattle. Five explanatory variables contributed 69.5 percent variability of the income from milk for all cattle holders. Experience in dairy farming had positive contribution to income from milk yield for all the cases of cattle farming and overall farming. Farm size had significant negative effect on milk yield in case of native and overall cattle holders because landless and marginal farmers usually preferred farming with native cattle. On the other hand, farm size had insignificant positive effect on milk yield incase of crossbred indicating that higher land owners rear crossbred cattle in many cases. The results highlight that per cow milk yield in native cow increases with the increase of number of milch cow in the herd. In contrast, in crossbred herd size does not affect milk yield per cow. The coefficient of time spent in cattle farming was statistically significant $(p<0.01)$ for native cattle, crossbred cattle and also for overall farming. In fact, the magnitude of the coefficient was the highest for crossbred cattle farming (2.004) indicating that if the time spent in crossbred cattle farming would have increased by 1 percent keeping others factor constant, milk value would have increased by 2 percent. Similarly, if the time spent in native cattle farming would have increased by 1 percent keeping other factors constant, milk value would have increased by 1.3 percent.

Table 6. Estimated values of coefficients and related statistics

\begin{tabular}{|c|c|c|c|c|}
\hline Independent variables & $\begin{array}{c}\text { Native } \\
\mathrm{N}=214\end{array}$ & $\begin{array}{c}\text { Crossbred } \\
\mathrm{N}=57\end{array}$ & $\begin{array}{l}\text { Mixed } \\
\mathrm{N}=9\end{array}$ & $\begin{array}{r}\text { Overall } \\
\mathrm{N}=280\end{array}$ \\
\hline Intercept & $\begin{array}{l}2.062^{\star \star} \\
(0.403)\end{array}$ & $\begin{array}{c}0.571 \\
(1.127) \\
\end{array}$ & $\begin{array}{l}1.912^{\star \star} \\
(0.341)\end{array}$ & $\begin{array}{c}1.895^{\star \star} \\
(0.350)\end{array}$ \\
\hline Experience $\left(\mathrm{X}_{1}\right)$ & $\begin{array}{c}0.240^{\star} \\
(0.113)\end{array}$ & $\begin{array}{c}0.027 \\
(0.156)\end{array}$ & $\begin{array}{c}0.115 \\
(0.066) \\
\end{array}$ & $\begin{array}{r}0.236^{*} \\
(0.096) \\
\end{array}$ \\
\hline Year of schooling of household head $\left(X_{2}\right)$ & $\begin{array}{l}-0.022 \\
(0.098)\end{array}$ & $\begin{array}{l}-0.559 \\
(0.233)\end{array}$ & - & $\begin{array}{l}-0.026 \\
(0.089)\end{array}$ \\
\hline Farm size based on cultivated land $\left(X_{3}\right)$ & $\begin{array}{l}-0.116^{*} \\
(0.054) \\
\end{array}$ & $\begin{array}{c}2.004 \\
(0.121) \\
\end{array}$ & - & $\begin{array}{l}-0.114^{*} \\
(0.049)\end{array}$ \\
\hline Time devoted in livestock farming (X4) & $\begin{array}{c}1.293^{\star \star} \\
(0.215)\end{array}$ & $\begin{array}{l}2.004^{\star \star} \\
(0.458)\end{array}$ & $\begin{array}{l}1.447^{\star \star} \\
(0.105)\end{array}$ & $\begin{array}{c}1.492^{\text {** }} \\
(0.150)\end{array}$ \\
\hline $\mathrm{R}^{2}$ & 0.478 & 0.967 & 0.983 & 0.695 \\
\hline
\end{tabular}

*Significant at $5 \%$ level probability, ${ }^{*}$ significant at $1 \%$ level of probability and '-'indicates error due to insufficient number of observations

The gross cost per cow per day was Tk.82 for native cows whereas Tk.175 for crossbred cow (Table 7). Concentrate feed cost per cow per day was Tk.48 for crossbred cow and Tk.12 for native cow i.e. crossbred cows were fed four times higher amount of concentrate to produce more milk (Table 3). The cost of green and dry fodder was almost double for crossbred cow and the labour cost was also higher. To determine the gross returns from dairy cows, returns from milk yield, value of cow-dung and value of calf were added. On the basis of the three sources of dairy returns there was much difference among the two types of cows. The overall gross returns indicate that milk yield provided 78 per cent of the total gross returns and cow-dung and calf provided 2 and 20 per cent returns respectively. Net return from crossbred dairy enterprise was Tk.28 per cow per day (16\% of the gross cost) whereas this figure is negative for native cow. This means that crossbred cattle farming is profitable but native cattle farming is not profitable. Farmers do not purchase labour and in some cases they do not purchase fodder specially, 
green grass and hence by dairy farming they earn more money than the above mentioned figures. The data of this research show that per day average labour was 4 hours of which only 0.3 hours (7.5\%) hired labour was purchased. Net return per cow per day was Tk.0.92 and the coefficient of concentrate feed (0.895) and labour (0.179) had a positive and significant effect on dairy return (Sikder et al., 2001).

Table 7. Per day cost and return of dairy cows (Taka) according to types

\begin{tabular}{|l|l|c|c|c|c|c|c|}
\hline & Items & \multicolumn{2}{|c|}{ Native } & \multicolumn{2}{c|}{ Crossbred } & \multicolumn{3}{c|}{ Overall } \\
\hline \multirow{4}{*}{} & Cost & & & & & & \\
& Interest of fixed capital & 9 & $(11.0)$ & 21 & $(12.0)$ & 11 & $(10.9)$ \\
& Green fodder & 16 & $(19.5)$ & 30 & $(17.1)$ & 19 & $(18.8)$ \\
& Dry fodder & 15 & $(18.3)$ & 28 & $(16.0)$ & 18 & $(17.8)$ \\
& Concentrate & 12 & $(14.6)$ & 48 & $(27.4)$ & 19 & $(18.8)$ \\
& Labour & 30 & $(36.6)$ & 48 & $(27.4)$ & 34 & $(33.7)$ \\
\hline A & Gross cost & 80 & $(100)$ & 175 & $(100)$ & 101 & $(100)$ \\
\hline & Return & & & & & & \\
& Value of milk & 54 & $(73.0)$ & 168 & $(82.8)$ & 81 & $(77.9)$ \\
& Value of cow-dung & 2 & $(0.27)$ & 3 & $(01.5)$ & 2 & $(01.9)$ \\
& Value of calf & 18 & $(24.3)$ & 32 & $(15.7)$ & 21 & $(20.2)$ \\
\hline B & Gross return & 74 & $(100)$ & 203 & $(100)$ & 104 & $(100)$ \\
\hline C & Net return (per cow per day) & -08 & & 28 & & 03 & \\
\hline D & Benefit cost ratio (C/A) & -0.10 & & 0.16 & & 0.03 & \\
\hline
\end{tabular}

Source: Own calculation from the surveyed data

* Figures in the parentheses are the percentages of total

Estimated at prices: Interest of fixed capital = (Total cost x 16\%) 365; green fodder @Tk. 2 per kg; dry fodder @ Tk. 3 per kg; concentrates @ Tk. 20 per kg; labour @ Tk. 10 per hour.

Out of 280 respondents 223 used to rear native cattle and all of them preferred native cattle because of lesser price of the animals to purchase and low input required. Most of them (91\%) claimed that rearing of native cattle was easy, 78 percent claimed easy to graze them and 65 percent gave opinion on their usefulness in draught purpose. About 45 percent of them claimed that native cattle were less prone to disease and 41 percent claimed high adaptability to local condition. Sixty eight percent of the respondents emphasized the easy accessibility of native bulls to mate their cows in time (Table 8).

Table 8. Proportion of respondents ranking of each preference of native cattle $(N=223)$

\begin{tabular}{|l|c|c|c|c|c|c|}
\hline \multirow{2}{*}{ Preferences } & \multicolumn{2}{|c|}{ Respondents } & \multicolumn{4}{c|}{ Extent of causes } \\
\cline { 4 - 7 } & \multicolumn{2}{|c|}{} & \multicolumn{3}{c|}{ High } & \multicolumn{2}{|c|}{ Low } \\
\cline { 3 - 7 } & Number & $\%$ & Number & $\%$ & Number & $\%$ \\
\hline Less purchase price & 223 & 100 & 172 & 77 & 51 & 23 \\
\hline Low input required & 223 & 100 & 181 & 81 & 42 & 19 \\
\hline Easy to rear & 203 & 91 & 160 & 79 & 42 & 21 \\
\hline Easy to grazing and grass land is available & 174 & 78 & 128 & 74 & 45 & 26 \\
\hline Use of duel purposes & 145 & 65 & 96 & 66 & 49 & 34 \\
\hline Native bull is available for mating & 112 & 68 & 59 & 53 & 53 & 47 \\
\hline Less prone to disease & 101 & 45 & 36 & 36 & 65 & 65 \\
\hline High adaptability & 92 & 41 & 67 & 73 & 25 & 27 \\
\hline
\end{tabular}

Source: Own calculation from the surveyed data

Out of 280 respondents surveyed (household) 223 used to rear indigenous milch cow and all of them could recall the number of milch cow per farm for the period 2006-2007. Out of these 214 respondents, 189, 117 and 98 respondents could state the actual number of milch cow for the period 2001-2005, 19962000 and 19991-1995 respectively. No other respondent was able to recall the actual number of milch cow for the period 1986-1990 and 1981-1985. Per farm average number of milch cow were 6, 4.7, 2.8 and 1.4 during the period 1991-1995, 1996-2000, 2001-2005 and 2006-2007 respectively. Maximum number of milch cow per farm was observed to be $25,20,8$ and 4 respectively, during the above period (Table 9). 
Table 9. Number of indigenous milch cow in different time periods

\begin{tabular}{|c|c|c|c|c|c|c|c|c|}
\hline \multirow[t]{2}{*}{ Period } & \multirow{2}{*}{$\begin{array}{l}\text { Number of } \\
\text { respondents }\end{array}$} & \multirow{2}{*}{$\begin{array}{c}\text { Maximum } \\
\text { number in a } \\
\text { farm }\end{array}$} & \multicolumn{6}{|c|}{ Average number of milch cow per farm } \\
\hline & & & $\begin{array}{l}\text { Mid- } \\
\text { region }\end{array}$ & Industrial & $\begin{array}{l}\text { North- } \\
\text { west }\end{array}$ & $\begin{array}{l}\text { Northern } \\
\text { hills }\end{array}$ & $\begin{array}{l}\text { South- } \\
\text { west }\end{array}$ & Overall \\
\hline 2006-2007 & 223 & 4 & 1.7 & 2.5 & 1.1 & 1.3 & 1.0 & 1.4 \\
\hline 2001-2005 & 189 & 8 & 3.0 & 3.8 & 2.7 & 2.5 & 2.4 & 2.8 \\
\hline $1996-2000$ & 117 & 20 & 3.5 & 6.0 & 4.5 & 4.1 & 8.0 & 4.7 \\
\hline 1991-1995 & 98 & 25 & 4.3 & 8.3 & 5.4 & 4.6 & 10.6 & 6.0 \\
\hline
\end{tabular}

Source: Own calculation from the surveyed data

Farmers surveyed were asked about the causes of reduction of native cattle. Major opinions were the low growth of the animals and hence not profitable (68\%) was on rank 1, low milk production (65\%) was on rank 2, crisis of feed and or high price of feed (62\%) was on rank 3, lack of source of investment (48\%) was on rank 4 and introduction of exotic breed (43\%) was on rank 5 . Lack of labour (40\%), lack of grass land due to increasing homestead and cultivated land (37\%) and crisis of straw due to the introduction of high yielding rice varieties (25\%) were important causes also. Causes of reduction of native cattle according to the percentage of respondents, their rank and the extent of causes are shown in Table 10.

All the farmers were asked to know their opinion on conservation of native cattle and about the constraints behind the conservation. Only 36 farmers were responded and most of them were from riverside and northern region. Responded farmers educated and well experienced on dairy farming but none of them had clear idea on conservation of native cattle. They wish to have improved native cattle instead of crossbred and they agreed that bio-diversity is affected due to rearing of crossbred cattle. Majority came up with the opinion that (i) to increase consciousness of rearing native cow and (ii) to run with crossing of purebred cows with local bulls. Some of them suggested (i) introduction of exotic breed should be stopped and (ii) native bull and cow should be promoted.

\section{Table 10. Causes of reduction of native cattle}

\begin{tabular}{|c|c|c|c|c|c|c|c|}
\hline \multirow[t]{2}{*}{ Causes of reduction } & \multirow{2}{*}{\multicolumn{2}{|c|}{$\begin{array}{l}\text { Respon- } \\
\text { dents }\end{array}$}} & \multirow{3}{*}{$\begin{array}{l}\text { Rank } \\
\text { of the } \\
\text { causes }\end{array}$} & \multicolumn{4}{|c|}{ Extent of causes } \\
\hline & & & & \multicolumn{2}{|c|}{ High } & \multicolumn{2}{|c|}{ Low } \\
\hline & No & $\%$ & & No & $\%$ & No & $\%$ \\
\hline Low growth and not profitable & 190 & 68 & 1 & 167 & 88 & 23 & 12 \\
\hline Low milk production & 181 & 65 & 2 & 154 & 85 & 27 & 15 \\
\hline Introduction of exotic breed & 119 & 43 & 5 & 94 & 79 & 25 & 21 \\
\hline Lack of source of investment & 135 & 48 & 4 & 82 & 61 & 53 & 39 \\
\hline Crisis of feed and or high price of feed & 174 & 62 & 3 & 145 & 83 & 29 & 17 \\
\hline Crisis of straw due to high yielding rice production & 71 & 25 & 9 & 40 & 56 & 31 & 44 \\
\hline $\begin{array}{l}\text { Lack of grass land due to increasing homestead and } \\
\text { cultivated land }\end{array}$ & 103 & 37 & 7 & 73 & 71 & 30 & 29 \\
\hline Lack of labour & 112 & 40 & 6 & 80 & 71 & 32 & 29 \\
\hline Absence of native bull & 45 & 16 & 11 & 33 & 73 & 12 & 27 \\
\hline Dairy farming is considered as an industrial enterprise & 95 & 34 & 8 & 70 & 74 & 25 & 26 \\
\hline $\begin{array}{l}\text { Changing trend of animal draught power to } \\
\text { mechanization }\end{array}$ & 63 & 23 & 10 & 52 & 82 & 11 & 18 \\
\hline $\begin{array}{l}\text { Used for dual (dairy and ploughing) purposes but now } \\
\text { expensive }\end{array}$ & 45 & 16 & 11 & 24 & 53 & 21 & 47 \\
\hline Brought land / selling cattle & 42 & 15 & 12 & 25 & 60 & 17 & 40 \\
\hline
\end{tabular}

Source: Own calculation from the surveyed data

As regards to constraints of native cattle genetic resource conservation data reveal that number of native cows gradually had been declined from 1991 to 2007. The major causes as came out from the opinion of respondents are switching over mechanized power instead of animal power in agricultural production, less profitability from native cows compared to crossbreds, lack of native breeding bulls in the community and lack of grass land due to increasing homestead and cultivated land. Some other constraints of reduction of native cattle keeping are low growth and milk production, introduction of exotic breed, lack of source of investment or credit support, limited coverage of veterinary services etc. Limited availability and lack of quality feed, especially, high price of concentrate feed is a serious constraint to keeping native cattle in the study areas. Land is a scare resource and it is rarely available for cultivation of green fodder 
and also grazing lands are limited due to extension of cereal crop production. Credit support to small native dairy farmers is limited and veterinary services such as disease diagnostic facilities and vaccines are inadequate and in most of the cases are not affordable.

\section{Conclusions and Recommendations}

It appears from the study that indigenous cattle genetic resource is declining in number day by day. This has been happening mostly because of indiscriminate crossbreeding through artificial insemination programme and gradual giving up of cattle husbandry by the rural poor farmers. Although crossbreds are high producing but they demand heavy initial investment as well as high maintenance cost which is unaffordable to majority farmers. Further, insufficiency of technical know how of the resource poor farmers is another obstacle for rearing crossbred cattle apart from biological adaptability issue of exotic inheritance. Situation described above dictates that indiscriminate breed substitution (with drawl of indigenous cattle) in our cattle population has been an incredible loss to our rural traditional agriculture. If immediate and appropriate measures are not taken to conserve our indigenous bovine genetic resources, an irrecoverable damage is likely to occur in the subsistence agriculture system of Bangladesh. The speculated damage includes loss of valuable FAnGR, loss of rural employment opportunity, loss of valued livestock products from indigenous animals, a decline in agricultural power system and degradation of many other allied issues.

\section{Acknowledgement}

The authour gratefully acknowledge the financial support of BAURES in conducting the research.

\section{References}

Annonym, 2006. Farm animal genetic resources: technical consideration for policy-makers concerning conservation and use. System-wide Genetic Resource Programme (SGRP), http://www.ipgr.egiar.org

Annonym, 2007. Status of the animal genetic measures. In: The State of the World's Animal Genetic Resources for Food and Agriculture. Commission on Genetic Resources for Food and Agriculture, FAO, Rome, Italy, 23pp.

Bayer, W., Lossau, A.V. and Feldmann, A. 2001. Small holders and community based management of farm animal genetic resources. Proceedings of Workshop held in Mbabane, Swaziland, 7-11 May, 2001. p. 1-12.

Bhuiyan, A.K.F.H. 2001. Sustainable Management of Animal Genetic Resources for Improving Human Livelihoods in Asia. $A$ Planning Workshop held at IRRI, Los Banos, The Philippines, 7-9 November, 2001. p. 1-4.

De Leeuw, P.N. and Wilson, R.T. 1987. Comparative productivity of indigenous cattle under traditional management in Sub-Saharan Africa. Quarterly Journal of International Agriculture, 2(4): 377-390.

FAO. 2007a. Uses and values of animal genetic resources. In: The State of the World's Animal Genetic Resources for Food and Agriculture. Commission on genetic resources for food and agriculture. Food and Agriculture Organization of United Nations, Rome, Italy, p. 77-100.

FAO. 2007b. Uses and values of animal genetic resources. In: The State of the World's Animal Genetic Resources for Food and Agriculture. Commission on genetic resources for food and agriculture. Food and Agriculture Organization of United Nations, Rome, Italy, p. 23-48.

FAO. 2008. Agriculture for animal diversity for agriculture (www.fao.org/docrep/010/a 1250 e/a 1250 e00.htm).

Gibson, J. Gamage, S. Honotte, O, Iniguez, L. Mailand, J.C., Rischkowsky, B., Semambo, D. and Toll, J. 2005. Options and strategies for the conservation of farm animal genetic resources. Paper presented in the international workshop at Agropolis, Montpellier, France. 7-10 November 2005.

Hodges, J. 2002. Conservation of farm animal biodiversity: history and prospects. Animal Genetics Resources Information, FAO, Rome. 32: 1-12.

Nuru, S. and Denis, S.M. 1976. Abortion and reproductive performance of cattle in Northern Nigeria: A questionnaire survey. Tropical Animal Health and Production 8: 213-219.

Sahai, R. 2001. Sustainability and conservation of farm animal genetic resources vis-à-vis challenges in India. Proc. Intl. Conf. on Sustainable Animal Production, Health and Environment: Future Challenges. Vol. 1. CCS Haryana Agril. Univ. Hisar. India. Nov. 24-27, 1999 p. 258-271.

Sikder, M.K.I., M.J. Alam and M.A. Samad Azad. 2001. Profitability and resource use efficiency of commercial dairy farms in Dhaka and Gazipur districts. Bangladesh Journal of Animal Science. 30(1-2): 115-122.

Singh, I.J. 1977. Elements of Farm Management. East-West Press, India, 32pp.

Wilson, R.T. and Clarke, S.E. 1975. Studies on the livestock of Southern Darfur, Sudan. The ecology and livestock resources of the area. Tropical Animal Health and Production, 7: 165-187. 